Silvija Meiere, Dr. iur.

Latvijas Universitāte, Latvija

\title{
VIDES TIESĪBU IZAICINĀJUMI 21. GADSIMTĀ
}

\section{CHALLENGES OF ENVIRONMENTAL LAW IN THE $21^{\text {sT }}$ CENTURY}

\begin{abstract}
Summary
The purpose of the article is to explore genesis of environmental laws in Latvia in the light of the relationship between Man and Nature. The article sharpens our historical understanding of the legal nexus between two regimes of law (environmental law and human rights law), and critically engages with the translation of environmental protection into an anthropocentric conceptual and operational legal framework. One important aspect of the relationship between environmental protection and human rights crowded out by anthropocentric filter is the widespread manifestation of conflicts between environmental protection laws and human rights. In order to improve environmental protection, environmental laws should be more ecologically oriented. One of the solutions would be an introduction of more extensive adaptive management in order to improve protection of ecosystems.
\end{abstract}

Atslēgvārdi: vides aizsardzība, subjektīvās vides tiesības, adaptīvā pārvaldība

Keywords: environmental protection, subjective environmental law, adaptive management

Tiesību doktrīnā izpratne par cilvēka un dabas mijiedarbību sakṇojas divās savstarpēji konkurējošās ideolog̣iskās pieejās (koncepcijās) - antropocentrismā un ekocentrismā. Pirmajā gadījumā dabas apsaimniekošana un aizsardzība primāri vērsta uz to, lai optimizētu dabas resursu izmantošanu, tādējādi apmierinot dažādas sabiedrības vajadzības un intereses. Otrajā gadījumā par prioritāru tiek atzīta nepieciešamība saglabāt dabas viengabalainību (veselīgas ekosistēmas), un dabas resursu izmantošana var notikt, nepārsniedzot ekosistēmu pastāvēšanai nepieciešamās robežas. Mūsdienu vides aizsardzība, tostarp vides tiesības, ir antropocentriskas, tomēr izpratne par cilvēka un dabas mijiedarbības raksturu nav akmenī iekalta, tā drīzāk ir pastāvīgi mainīga, un par to liecina vides tiesību attīstības gaita kopš to pirmsākuma līdz mūsdienām. Simt gadu laikā, kopš pastāv Latvijas valsts, vides tiesiskā aizsardzība attīstībā ir piedzīvojusi vairākus posmus. Lai gan pēdējās desmitgadēs vides tiesību normu skaits ir dramatiski pieaudzis, dabas degradācija joprojām turpinās. ${ }^{1}$

1 Pēc Ekonomiskās sadarbības un attīstības organizācijas (angḷu val. - OECD) 2019. gadā sagatavotā vides pārskata par Latviju, "[d]abiskās vides stāvoklis ir slikts un turpina pasliktināties. Tikai 10 \% biotopu ir labvēlīgs aizsardzības statuss. [..] Lielāko apdraudējumu rada zemes lietošanas veida maiṇa, sadrumstalotỉba, intensiva resursu izmantošana, piesārṇojums un lauksaimnieciskās darbības paplašināšanās." Pieejams: www.oecd.org/env/country-reviews/ [aplūkots 03.06.2019.]. 
Šã raksta mērḳis ir akcentēt uzmanību, ka pašlaik atrodamies tādā attīstības posmā, kad, ņemot vērā zinātnes faktus un jaunākās atziņas par dabā notiekošajiem procesiem un to dinamiku, ir nobriedusi nepieciešamỉba pārskatìt pašreizējo pieeju vides aizsardzībai un mazināt tajā valdošo antropocentrismu. Lai sasniegtu mērkịi, tiek izvirzīi šādi uzdevumi - raksturot vides tiesību attīstïbu no to pirmsākumiem līdz mūsdienām; atklāt iemeslus, kāpēc valdošā antropocentriskā pieeja nevar nodrošināt tik efektīvu vides aizsardzību, lai apturētu dabas degradāciju; iezīmēt iespējamo attīstības virzienu, kas būtiski uzlabotu vides aizsardzību.

Pirmās vides tiesības radās jau 19. gadsimtā un pastāvēja galvenokārt t. s. dabas aizsardzības konservatīvajā formā, kas paredzēja cilvēka neskartas dabas vai skaistu ainavu saglabāšanu îpaši aizsargātās dabas teritorijās. Latvijā 20. gadsimta 20.-30. gados tika izveidotas vairākas īpaši aizsargājamas dabas teritorijas, ar likumu tika regulēta meža aizsardzība un medības, ar Ministru kabineta noteikumiem bija noteikta dižkoku un bebru aizsardzība. ${ }^{2}$

20. gadsimta otrajā pusē blakus dabas saglabāšanas regulējumam parādijjās arī tiesību normas, kuru mērḳis bija aizsargāt dabu cilvēka interesēs. Šie likumi attiecās uz dabas resursiem (zemi, zemes dzīlēm, ùden̦iem, mežu u. c.). ${ }^{3}$ Lai gan formāli šie likumi paredzēja dabas resursu aizsardzību, to galvenais princips bija sekmēt dabas resursu racionālu izmantošanu, lai apmierinātu dažādas ekonomiskās vajadzības (intereses). ${ }^{4}$ Kopumā līdz 20. gadsimta 60.-70. gadu mijai, kad globālā mērogā vides aizsardzībā notika būtiskas pārmaiñas, pirmie centieni aizsargāt dabu bija motivēti dažādi - gan ar mērḳi pasargāt dabu no cilvēka, novērst tās iznīcināšanu nelielās cilvēka neietekmētās dabas "salin̄ās", gan ar mērḳi nodrošināt labvēlīgus apstākḷus "derīgo" dabas resursu saprātīgai ekspluatācijai. Taču šie atšķirīgie mērḳi izrietēja no viena valdošã uzskata starp cilvēku (sabiedrību) un dabu pastāv antagonisms. Tāpēc sākotnējās vides tiesības nebija un arī nevarēja būt saistìtas ar nepieciešamību harmonizēt cilvēka un dabas līdzāspastāvēšanu.

Ideja, ka cilvēkam ir jārūpējas par dabu savas izdzīvošanas interesēs, nostiprinājās tikai 20. gadsimta 60. gados, kad galvenokārt ekonomiski attīstītāko valstu pilsoniskā sabiedrība sāka izprast un apzināties, ka cilvēku radītais vides kaitējums (t. sk. piesārn,ojums) apdraud pašu cilvēku dzīvību un veselību. Cilvēki apkārtējo vidi sāka uztvert kā jutīgu un neaizsargātu sistēmu, kas ir atkarīga no cilvēka labās gribas, rīcības un rūpēm. ${ }^{5}$ Minētā izpratne noteica un joprojām caurvij mūsdienu vides tiesības, kuras intensīvi sāka veidoties 60.-70. gadu mijā. Būtiskās pārmaiņas cilvēka attieksmē pret dabu - vides aizsardzības centrā tika izvirzìts cilvēks ar viņa interesēm un vajadzībām

2 Strautmanis J. Ekologisko tiesību pamati. Dabas vides tiesiskā aizsardzība. Rīga: Zvaigzne ABC, 1997, 30. lpp.

3 Latvijā pirmais kompleksais likums dabas aizsardzībā tika pieṇemts 1959. gadā, šis likums jaunā pilnveidotā redakcijā tika pieņemts 1968. gadā. 60.-70. gados tika izstrādāti un pieņemti zemes, zemes dzịḷu, meža kodeksi, kā arī likums par gaisa aizsardzību un savvaḷas dzīvnieku aizsardzību.

4 Birnie P., Boyle A., Redgwell C. International Law \& the Environment. 3rd. ed. New York: Oxford University Press, 2009, p. 585; Strautmanis J., 108. lpp.

5 Petersmann M. C. Narcissus' Reflection in the lake: Untold Narratives in Environmental law Beyond the Anthropocentric Frame. In: Oxford Journal of Environmental Law, Vol. 30, Issue 2, 2018, pp. 235 259. 
pēc dzīvībai un veselībai labvēlīgas vides, kuras kvalitāte ir jānodrošina valstij, sadarbojoties ar sabiedrību. "Daba ir aizsargājama tikai tādā mērā, ja tas atbilst cilvēku interesēm, nevis abstraktām dabas saglabāšanas prasībām.” Cilvēka un dabas mijiedarbības antropocentriskajā izpratnê $\overline{-}^{-7}$ mērogs cilvēka attiecībām ar dabu ir pats cilvēks, kas ietver visas nākamās paaudzes. Dabai ārpus cilvēka ir tikai atvasināta vērtība. Šāda izteikti antropocentriska vides aizsardzība, kas apkaro galvenokārt vides piesārṇojumu, lai primāri kalpotu cilvēku veselības un labklājības nodrošināšanai, iezīmēja līdz tam vēl nebijušu vides aizsardzỉbas perspektīvu un lielākoties līdz pat šim laikam ir noteikusi mūsdienu vides tiesību attīstību.

Globālā mērogā pārorientēšanos uz antropocentrisku vides aizsardzību, kurai jākalpo cilvēka labumam, iezīmēja ANO Stokholmas deklarācija "Par cilvēka vidi" (1972). Tajā pirmo reizi vides aizsardzība tika aplūkota kā joma, kas ir cieši saistīta ar cilvēktiesībām. ${ }^{8}$ Ieguvums no šādas stratēgijas bija vides aizsardzības juridiskā ranga paaugstināšana. Tika radīti arī apstākḷi sabiedrības mobilizēšanai un labākai iesaistei vides aizsardzībā.

Minētā iespaidā vides aizsardzība kḷuva par vienu no starptautisko tiesību prioritātēm, attīstījās un nostiprinājās juridiskā prakse, kas atsevišķu vispāratzīto cilvēktiesību saturā atklāja vides aspektus un apliecināja, ka cilvēktiesību aizsardzības garantijas ir iespējams izmantot arī vides aizsardzības mērḳu sasniegšanai. Vides aizsardzība tika atzìta par leǵitīmu cilvēktiesību ierobežošanas mērḳi, kā arī par nozīmīgu apsvērumu taisnīga līdzsvara noteikšanai starp cilvēka pamattiesībām un vispārējām interesēm. Piemēram, Eiropas Cilvēktiesību tiesa ir atzinusi, ka finansiāliem apsvērumiem, pat tiesībām uz īpašumu, nedrīkst piešķirt prioritāti pār vides aizsardzības apsvērumiem, ja tie izriet no nepieciešamības ievērot vides likumu prasības. ${ }^{9}$ Tomēr visai drīz atklājās, ka vides aizsardzības mērķus ar tradicionālo cilvēktiesību aizsardzības sistēmas palīdzību var sasniegt visai ierobežotā veidā. Šì aizsardzības sistēma var aptvert vides piesārn,ojumu, taču ārpus tās ietvara paliek daudzas citas dabas degradācijas formas (piemēram, biolog̣iskās daudzveidības samazināšanās), kurām uz individuālajām cilvēktiesībām parasti ir netieša ietekme un tāpēc tā nav pietiekama, lai atzītu cilvēktiesību aizskārumu. ${ }^{10}$

Salīizinājumā ar sākotnējām vides tiesībām, kuras bija relatīvi ekocentriskas ${ }^{11}$, vides aizsardzības sasaiste ar cilvēktiesībām mūsdienu vides tiesības ir padarījusi par

6 Strautmanis J., 53. lpp.

7 Antropocentrisms ir viena no ekologiskās ètikas dispozīcijām. Plašāk sk. Rubenis A. Ẽtika 20. gadsimtā. Praktiskā ētika. Rìga: Zvaigzne ABC, 1996, 130.-138. lpp.

8 Declaration of the United Nations Conference on the Human Environment, Stockholm, 16 June 1972, UN Doc A/CONF/48/14/REV. Deklarācijas 1. pants noteic, ka cilvēkam ir pamattiesības uz brīvību, vienlīdzību un adekvātiem dzīves apstākḷiem vidē, kuras kvalitāte nodrošina cilvēka dzīvību, cieṇu un labklājību un ka cilvēks ir arī atbildīgs par vides saglabāšanu un uzlabošanu esošās un nākamo paaudžu interesēs.

9 Eiropas Cilvēktiesību tiesas 2007. gada 27. novembra spriedums lietā Hamer v. Belgium, (21861/03), 79. punkts.

10 Eiropas Cilvēktiesību tiesas 2003. gada 22. maija spriedums lietā Kyrtatos v. Greece, (41666/98), 52. punkts.

11 Saskaņā ar ekologiiskās ētikas holistisko (ekocentrisko) dispozīciju, cien̦as vērts (respektējams) ir ne tikai cilvēks, bet arī daba (dzīvās un nedzīvās dabas kompleksās sistēmas); sk. Rubenis A., 132. lpp. 
izteikti antropocentriskām tiesībām, jo galvenais labuma guvējs no vides aizsardzības ir cilvēks, nevis daba. ${ }^{12}$

Latvijā pāreja uz antropocentrisku vides aizsardzību notika līdz ar valstiskās neatkarības atjaunošanu. Vides aizsardzības paradigmas nomaiņa bija spilgti redzama pat semantikā - normatīvajos aktos termins "daba" tika aizstāts ar terminu "vide"13. Savukārt "daba" kḷuva par "dabas faktoru” un cilvēka dzīves vides elementu" ${ }^{14}$.

Līdzīgi kā daudzās pasaules valstīs, arī Latvijā vides aizsardzībai ir konstitucionāls rangs. ${ }^{15}$ Nenoliedzami, tas ir ietekmējis gan tiesību jaunradi, gan piemērošanu. Tiesību doktrīnā uzsvērts, ka, izpildot pienākumu aizsargāt vidi, visu valsts varas nozarojumu darbībai vajadzētu kḷūt "ekolog̣iskākai" ${ }^{16}$ To, ka tendence - ņemt vērā vides apsvērumus - valsts darbībā pastāv, apliecina arī šāds tiesu prakses piemērs, kur tiesa dabas resursus (mežus un ūdenstilpes) vērtē ne tikai kā īpašuma, bet arī dabas objektus. Tiesas skatījumā šo objektu duālais raksturs padara tos par īpašiem tiesību objektiem, jo to izmantošana un aizsardzība ir cilvēka kā biolog̣iskas un sociālas būtnes pastāvēšanas vide, cilvēka un sabiedrības eksistences un attīstības priekšnosacijums, tautas labklājības pamats. Lìdz ar to likumdevējam ir jānosaka tāds tiesiskais regulējums, kas paredzētu arī šo objektu īpašniekiem pievienoties Konstitūcijā nostiprinātajai sabiedrības vides aizsardzības interesei tādā veidā, lai vinam īpašumā esošã zeme, meži un ūdenstilpes tiktu izmantotas tikai pienācīgi un racionāli; lai ar šiem objektiem netiktu nodarīts kaitējums videi. ${ }^{17}$

Turklāt Latvijas vides tiesību īpatnība bija tā, ka valsts atzina: cilvēkam ir ne vien morālas, bet vienlaikus arī juridiski aizsargātas tiesības uz vidi. Pirmo reizi sabiedrības tiesības dzīvot kvalitatīvā vidē bija paredzētas 1991. gada likumā "Par vides aizsardzību”. Dažus gadus vēlāk šo tiesību juridiskais rangs tika paaugstināts - tiesības dzīvot labvēlīgā vidē kā cilvēka pamattiesības ir spēkā kopš 1998. gada ${ }^{18}$, un Satversmes tiesa ir atzinusi, ka visas pamatlikumā garantētās pamattiesības ir piemērojamas tieši un nepastarpināti, kā arī vienlīdz respektējamas un aizsargājamas ${ }^{19}$. Atsevišķ̧u tiesību

12 Petersmann M. C., 2018, pp. 235-259.

13 Semantiski videi ir telpiska nozīme - kā apkārtne, viss, kas ir ap mani; un ir nepārprotami skaidrs, ka tieši cilvēks atrodas šīs telpas centrā; tā ir vieta, kur cilvēks atrodas saskarē ar dabu.

14 Sal. sk. Vides aizsardzības likuma 1. panta 17. punktu, kur vide tiek definēta kā dabas, antropogēno un sociālo faktoru kopums. Vides aizsardzības likums: LV Likums. Latvijas Vēstnesis, 2006. 15. novembris, Nr. 183.

15 Satversmes 115. pants. Latvijas Republikas Satversme: LV Likums. Latvijas Vēstnesis, 1993. 1. jūlijs, Nr. 43.

16 Klepfers M. Vides aizsardzība konstitucionālajās tiesībās: Vācijas Pamatlikuma 20.a pants. No: Likums un Tiesibas, 5. sēj., Nr. 11 (51), 2003. novembris, 328. lpp.

17 Citēts no Lietuvas Konstitucionālās tiesas tiesneša Armana Abramavičus referāta "Konstitucionālie vides aizsardzības aspekti Lietuvas Republikas Konstitucionālās tiesas jurisprudencē” tēzēm. No: Konstitucionālie vides aizsardzības aspekti konstitucionālās tiesas jurisprudencē un citas konstitucionālās jurisprudences problēmas. Viḷna: Lietuvas Republikas Konstitucionālā tiesa, 2009, 109.110. lpp.

18 Grozijumi Latvijas Republikas Satversmē: LV Likums. Latvijas Vēstnesis, 1998. 23. oktobris, Nr. 308/312.

19 Satversmes tiesas 2007. gada 21. decembra spriedums lietā Nr. 2007-12-03. Latvijas Vēstnesis, 2007. 28. decembris, Nr. 207. 
uz labvēlīgu vidi izdalī̌sana savulaik tika pamatota ar nepieciešamību vides kvalitātei pieškịt citiem konkurējošiem mērḳiem līdzvērtīgu statusu. ${ }^{20}$ Būtībā šīs tiesības ir inovatīvas cilvēktiesības, jo tās vairāk ir vērstas uz vides aizsardzību (vides likumu un vides pārvaldības uzlabošanu), nevis uz pastiprinātu cilvēka individuālās labklāiības aizsardzību tradicionālajā cilvēktiesību izpratnē. ${ }^{21}$

Minētajā apstāklī slēpjas gan teorētiskas, gan ar šo tiesību īstenošanu saistītās problēmas. Jebkuras cilvēktiesības, arī tiesības uz labvēlīgu vidi, tiek atvasinātas no antropocentrisma pozīcijām ${ }^{22}$, tādēl šo tiesību ekocentriska interpretācija nesaskan ar tradicionālo izpratni par cilvēktiesībām. Turpretī cilvēka vajadzību pēc veselību un labklājību nodrošinošas vides hipertroficēšana tiesības uz labvēlīgu vidi viegli var pārvērst par "supertiesībām”, kas nonāktu pilnīgā pretrunā ar to ieviešanas mērḳi. Neraugoties uz minēto nenoteiktību, Satversmes 115. pants vides aizsardzībai vismaz formāli ir piešḳīis citām konstitucionāli aizsargātām vērtībām līdzvērtīgu svaru, kā arī pavēris iespēju tiesā pārbaudìt valsts un pašvaldību rīcības (lēmumu) atbilstību cilvēka tiesībām dzīvot labvēlīgā vidē (tostarp, vai valsts un pašvaldỉbas savā darbībā ievēro vides normatīvo aktu prasības).

Vides aizsardzības un cilvēktiesību sasaiste izrietēja no pieņēmuma, ka abas jomas vieno kopīgs mērḳis - labāki dzīves apstākḷi cilvēku sugai. Taču vides aizsardzības pavērsiens antropocentrisma virzienā nesniedz pilnīgu cilvēka un dabas attiecību atspoguḷojumu. Cilvēka un dabas reālās attiecības ir daudz sarežğìtākas. Viena no ēnā esošajām realitātes šḳautnēm ir konflikti, kuri veidojas starp vides aizsardzību un cilvēktiesībām. Proti, nepieciešamība uzturēt dabisko sistēmu funkcionēšanu var prasît loti būtiskus cilvēktiesību ierobežojumus, tāpēc vides aizsardzībai var būt arī negatìva ietekme uz cilvēktiesībām. ${ }^{23}$

Līdz šim valdošās antropocentrisma dogmas ietekmē vides aizsardzỉbas un cilvēktiesību konflikti ir maz pētīti, īpaši trūkst izpētes par to, kā šos konfliktus varētu risināt. Minēto konfliktu risināšanā vērā n,emamu uzlabojumu nav devušas arī tiesības uz labvēlīgu vidi. Lai gan šo tiesību garantēšanai valstij jānodrošina efektīva vides aizsardzības sistēma ${ }^{24}$, tās nav absolūtas un a priori neparedz pastāvošās vides nemainīgumu, kā arī pašas par sevi neliedz īstenot ekonomiskās vai sociālās intereses. ${ }^{25}$ Satversmes tiesa ir atzinusi, ka, lemjot par vides izmantošanu, vienmēr ir jāizvēlas, kurām interesēm - vides aizsardzībai vai ekonomiskajām interesēm - konkrētajos apstākḷlos dodama priekšroka. Tāpat, arī vērtējot iespējamos Satversmes 115. panta pārkāpumus, pēc iespējas jālīdzsvaro sabiedrības ieinteresētība dzīvot labvēlīgā vidē, no vienas puses, un

20 Birnie P., Boyle A., Redgwell C., p. 278.

21 Meiere S., Čepāne I. Latvijas Republikas Satversmes 115. panta komentārs. Grām.: Latvijas Republikas Satversmes komentāri. VIII nodaḷa Cilvēka pamattiesības. Rīga: Latvijas Vēstnesis, 2011, 717.736. lpp.; Satversmes tiesas 2017. gada 19. decembra sprieduma lietā Nr. 2017-02-03 16. p. Latvijas Vēstnesis, 2017. 21. decembris, Nr. 254.

22 Sal. sk. Satversmes tiesas 2017. gada 19. decembra spriedumu lietā Nr. 2017-02-03 19.1.p.

23 Petersmann M. C., pp. 235-259.

24 Satversmes tiesas 2007. gada 21. decembra spriedums lietā Nr. 2007-12-0313. p. Latvijas Vēstnesis, 2007. 28. decembris, Nr. 207.

25 Turpat, 9.2. punkts; Satversmes tiesas 2008. gada 17. janvāra spriedums lietā Nr. 2007-11-03 13, 13.2. punkts. Latvijas Vēstnesis, 2008. 23. janvāris, Nr. 12. 
saimnieciskās attīstỉbas veicināšana, no otras puses ${ }^{26}$ Redzams, ka lēmumu pien̦emšanā izškiršanās par to, kuram aspektam - attīstībai, cilvēku labklājībai vai vides aizsardzībai - dodama priekšroka, joprojām ir lēmuma pien̦ēmēja ziņā.

Kā tas ietekmē konkrētu lēmumu pieņemšanas praksi, ilustrē šāds piemērs. Novada pašvaldība izstrādāja plūdu riska novēršanas projektu. Projektu izvērtējot, tika konstatēts, ka, izbūvējot dambi projektā paredzētajā vietā (upes palienē), tiks degradēts un iznīcināts Eiropas Savienības prioritāri aizsargājams biotops (aluviāli krastmalu un palien,u meži) aptuveni 38 ha platībā, biotopa kopējo platību Latvijas teritorijā samazinot par 0,5 \%. Dabas aizsardzības pārvalde ietekmi vērtēja kā būtiski negatīvu un pauda viedokli, ka dambja izvietojumam pastāv cita reāla alternatīva, kas l̦autu palienes mežu saglabāt. Taču pašvaldỉba, atsaucoties uz papildu izmaksām un projekta īstenošanas steidzamību, tam nepiekrita. Vides aizsardzības un regionālās attīstības ministrija sagatavoja informatīvo ziņojumu par to, ka projekta apdraudētais biotops neatrodas Eiropas nozīmes īpaši aizsargājamā dabas teritorijā, tādēl likums neizvirza striktu prasību atteikties no dambja paredzētã izvietojuma. Ministru kabinets projektam noteica nacionālo interešu objekta statusu, ${ }^{27}$ būtībā akceptējot, ka projekta, kas samazinās plūdu negatīvo ietekmi uz novada iedzīvotāju veselību, īpašumu un saimniecisko darbību un tādējādi aizsargās iedzīvotāju tiesības dzīvot labvēlīgà vidē, realizēšana steidzamā kārtā un nemeklējot dabai draudzīgāku risinājumu, ir nozīmīgāka par apdraudēta, turklāt īpašai aizsardzībai pakḷauta dzīvās dabas objekta (biotopa) iznīcināšanu.

Minētais liecina, ka nepieciešamība rūpīgi izvērtēt dažādus lēmumu aspektus un saskaņot dažãs intereses vides aizsardzības "svaru" ikdienas lēmumu pien̦emšanā nav būtiski palielinājusi. Ja nav likuma ar noteiktu ierobežojumu vai aizliegumu, kas paredzēts vides aizsardzībai, izšķiršanās joprojām lielākoties notiek par labu citām interesēm. Turklāt tas tā ir pat tad, ja vides aizsardzības intereses prasìtu vienīgi projekta izmain,as, nevis liktu atteikties no projekta pavisam.

Lai vides aizsardzību patiešām uzlabotu, nepieciešama lielāka konceptuāla skaidrība par to, kā interešu līdzsvarošanas gadỉjumā būtu izdarāma izvēle starp vides aizsardzības un citām konstitucionāli aizsargātām interesēm (vērtībām). Taču šobrīd nav nedz stratēgisku prioritāšu, nedz kritēriju, kas ḷautu noteikt, kurām interesēm (vides aizsardzībai vai attīstībai) noteiktos apstākḷ̆os būtu dodama priekšroka. Šis aspekts ir nozīmìgs arì konstitucionālā ilgtspējīgas attīstības principa kontekstā, jo skar tā pịlāru (ekonomika, sociālā sfēra, vide) kolīiju. Minētais piemērs rāda, ka līdz šim ilgtspējīgas attīstības sociālā pīlāra (cilvēku labklājība) un vides aizsardzības pīlāra konfliktu risināšanā tiesības uz labvēlīgu vidi, kam būtu jāveicina labāka vides aizsardzība, faktiski vides aizsardzības līmeni nav būtiski uzlabojušas.

Pašlaik dominējošā antropocentriskā pieeja vides aizsardzībai (vides tiesību antropocentrisms), kas par galveno mērauklu vides aizsardzībai uzskata cilvēku, ir izveidojusies un nostiprinājusies pēdējo piecdesmit gadu laikā. Taču pati par sevi tā

26 Satversmes tiesas 2017. gada 19. decembra spriedums lietā Nr. 2017-02-03 20. p. Latvijas Vēstnesis, 2017.21. decembris, Nr. 254.

27 Ministru kabineta 2014. gada 19. marta rîkojums Nr. 123 "Par nacionālo interešu objekta statusa noteikšanu Gaujas upes lejteces pretplūdu aizsardzības infrastruktūras būvēm Carnikavas novadā”. 
neatspoguḷo cilvēka un dabas mijiedarbības ontologisko būtību. Speciālajā literatūrā arvien vairāk nostiprinās uzskats, ka antropocentriskā vides aizsardzība pilnīgi neatsedz vides problēmu būtîbu un līdz galam neapzinās ekologijas sniegtos faktus. ${ }^{28}$ Tāpēc ir nobriedusi nepieciešamība vides tiesības padarīt vairāk ekologiskas, tas ir, tādas, kas vairāk atbilstu zinātnes atziṇām par cilvēka un dabas mijiedarbỉbas raksturu un būtību.

Ekologijā daba ir nevis ekspluatējami dabas resursi, bet gan integrētas biologiskās sistēmas, kuras savstarpēji pārklājas. Daba ir dzīvo būtṇu pasaule, kurā dzīās būtnes veido savstarpējo mijiedarbību "audeklu" - tās ir pastāvīgi nodarbinātas, "ražojot preces un pakalpojumus", kas ir būtiski citiem. Savukārt ekosistēma ir dabas "globālās ekonomikas" apakškopa, vietēja vai regionāla augu, mikroorganismu, dzīvnieku sistēma, kurā tās komponenti mijiedarbojas, lai izdzīvotu. ${ }^{29}$ Dzìvo sistēmu dažādība, sākot ar gēniem un beidzot ar ainavām un ekosistēmu pakalpojumiem, rada un nodrošina bāzi, no kuras ir atkarīga sociālā un ekonomiskā attīstība.

Kā biologiska suga cilvēks ir ekosistēmu komponents. ${ }^{30}$ Tātad, pēc zinātnes atziñām, globālā cilvēku sabiedrība (kopiena) ir biosfēras komponents. Nostiprinās uzskats, ka pašlaik noris pāreja uz tādām ekosistēmām, kurās dominē cilvēks, tādēḷ sociālās sistēmas un ekosistēmas vairāk nevar aplūkot atrauti. ${ }^{31}$ Proti, sociālās sistēmas (ieskaitot cilvēktiesības) ir "iegremdētas” sarežgitās un mijiedarbībā evolucionējošās dabas sistēmās (ekosistēmās). Tāpēc cilvēki nav nodalāmi no savas vides (dabas), tie kopā ar citām dzīvajām būtnēm un abiotiskiem procesiem ir šìs sistēmas līdzveidotāji. Šāda apvienotā sociāli ekolog̣iska dubultsistēma ir sarežgítāka par jebkuru citu sistēmu, kāda, apskatot sabiedrības un dabas mijiedarbību, ir bijusi pazīstama. Tas nozìmē: ja vēlamies pietiekami efektīvi pārvaldīt cilvēka un dabas mijiedarbību, mums būs jāiemācās sadzīvot ar šādai sistēmai raksturīgo sarežgitîibu un dinamismu (nepārtrauktām pārmaiṇām tajā). Ir skaidrs, ka šādu sistēmu pārvaldỉbai vairs neder jau aprobētās pieejas. Tādēḷ visai intensīvi tiek meklēti inovatīvi risinājumi, un pakāpeniski veidojas izpratne, uz kādiem principiem būtu balstāma pārvaldỉba. ${ }^{32}$

Minētajai vides (ekosistēmu) pārvaldības sistēmai vajadzētu būt tādai, kurā: 1) tiek prognozēti izmaiņu scenāriji un veikti pasākumi, lai nevēlamās izmaiṇas laikus novērstu; 2) tiek būtiski uzlabota spēja pielāgoties mainīgiem apstākḷiem; 2) spēj rīkoties zinātniskās nenoteiktības situācijā (jo zinātne nespēj sniegt atbildes uz visiem jautājumiem).$^{33}$ Meklējot mehānismu, kas varētu veicināt sociāli ekologiskās sistēmas

28 Petersmann M. C., pp. 235-259; Turgut N. Y. The Influence of Ecology on Environmental Law: Challenges to the Concept of Traditional Law. RECIEL, 2008.

29 Birnie P., Boyle A., Redgwell C., p. 585.

30 Vides zinātne. M. Kḷaviņš (red.). Rīga: LU Akadēmiskais apgāds, 2008, 313. lpp.

31 Young O. R. Navigating the Sustainability Transition: Governing Complex and Dynamic Socioecological Systems. In: Global Environmental Commons. Analytical and Political Challenges in Building Governance Mechanisms. E. Brousseau, T. Dedeurwaerdere, P.-A. Jouvet, M. Willinger (eds.). New York: Oxford University Press, 2012, p. 81.

32 Sk., piem., McDonald J., Styles M. C. Legal Strategies for Adaptive Management under Climate Change. Oxford Journal of Environmental Law, Vol. 26, Issue 1(March), 2014, pp. 25-53.

33 Young O. R., pp. 87-88. 
noturību (resilience) $)^{34}$, starpdisciplinārajā literatūrā kā risinājums tiek piedāvāta valsts un sabiedrības kopīgi īstenota (collaborative governance) ekosistēmu adaptīvā pārvaldība (adaptive management). ${ }^{35}$ Adaptīvās pārvaldības mērḳis ir veicināt ekosistēmu noturību, n,emot vērā sociāli ekolog̣iskās mijiedarbības. Adaptīvajā pārvaldībā būtiska ir pielāgošanās mainīgajiem apstākḷiem, kas ietver strukturētu lēmumu pien,emšanu, kur, reagéjot uz jaunu informāciju, noris mācīšanās, plānoto rīcību pārvērtēšana un pārskatīšana.

Vēl tikai sāk veidoties izpratne par pārvaldību, kas var risināt ekosistēmu noturības jautājumus. Nozīmīgs solis šajā virzienā ir dabas resursa pārvaldība, izmantojot ekosistēmas pieeju. ${ }^{36}$ Ekosistēmu pārvaldības mērḳis ir saglabāt un uzlabot ekosistēmu veselību vai ekologiskās funkcijas. ${ }^{37}$ Ievērojot Eiropas Savienības tiesisko regulējumu, Latvijā šāda pieeja saldūdens un jūras apsaimniekošanā jau ir noteikta un tiek îstenota. Tā ietver vairākus nozīmīgus adaptīvās pārvaldības komponentus - ciklisku plānošanu (progresa rezultātu novērtējums ik pēc sešiem gadiem), kuras mērḳis ir panākt visu ūdeṇu labu ekologisko stāvokli. Pamatojoties uz dabiskajiem ǵgeogrāfiskajiem upju baseiniem, valstij ir likumā noteikts pienākums sagatavot upju baseinu apsaimniekošanas plānus, kā arī izstrādāt konkrētu programmu un pasākumus, lai paredzēto mērḳi sasniegtu. ${ }^{38}$ Tomēr šim regulējumam ir arī vairāki būtiski trūkumi, tas nav pietiekami efektīvs, jo piešķir pārāk plašu izvēles brīvību sasniedzamo vides stāvokḷa uzlabošanas mērḳu noteikšanā un vēlāk - arī to sasniegšanā. ${ }^{39}$

Atš̌kirībā no ūdens ekosistēmām sauszemes ekosistēmu pārvaldības sistēmas, neraugoties uz dažiem iedīgliem (îpaši aizsargājamo dabas teritoriju dabas aizsardzības plāni ${ }^{40}$, ipaši aizsargājamo sugu un biotopu aizsardzības plāni ${ }^{41}$ ), pašlaik vēl ir l̦oti vājas un neattīstītas. Izstrādātie plāni ir rekomendatīvi, bieži netiek îstenoti, jo esošais tiesiskais regulējums neparedz mehānismu, kas nodrošinātu plānoto pārvaldības mērḳu sasniegšanu.

Adaptīvā pārvaldība var būt spēcīgs rīks ekosistēmu noturības veicināšanai. Speciālajā literatūrā jau ir attīstīti un noformulēti šìs pārvaldỉbas sistēmas atribūti un

34 Sistēmas spēja absorbēt ārējās ietekmes, nezaudējot savu funkciju. Resilience ir ekolog̣ijas jēdziens, kas arvien vairāk nostiprinās tiesību doktrīnā, it īpaši klimata pārmaiṇu kontekstā. Plašāk sk. piem., Kessen A. M., van Rijswick H. F. M. W. Adaptation to Climate Change in European Water Law. Utrecht Law Review, Vol. 8, Issue 3 (November) 2012.

35 Jenkins V. Sustainable management of natural Resources: Lessons from Wales. Oxford Journal of Environmental Law, Vol. 30, Issue 3 (November), 2018, pp. 399-423; Turgut N. Y., 2008.

36 Sk. plašāk: De Lucia V. Competing Narratives and Complex Genealogies: The Ecosystem Approach in International Environmental Law. Oxford Journal of Environmental Law, Vol. 27, Issue 1, 2015, pp. 91-117.

37 Turgut N. Y., 2008.

38 Ūdens apsaimniekošanas likums. Ūdens apsaimniekošanas likums: LV Likums. Latvijas Vēstnesis, 2002. 1. oktobris, Nr. 140.

39 Kessen A. M., van Rijswick H. F. M. W., 2012.

40 Likums "Par īpaši aizsargājamām dabas teritorijām”": LV Likums. Latvijas Vēstnesis, 1993. 25. marts, Nr. 5; Noteikumi par īpaši aizsargājamo dabas teritoriju dabas aizsardzības plāna saturu un izstrādes kārtību: Ministru kabineta 2007. gada 9. oktobra noteikumi Nr. 686. Latvijas Vēstnesis, 2007. 12. oktobris, Nr. 165.

${ }^{41}$ Sugu un biotopu aizsardzïbas likums: LV Likums. Latvijas Vēstnesis, 2000. 5. aprīlis, Nr. 121/122. 
darbības principi. Taču līdz šim uzkrātā pieredze liecina ${ }^{42}$, ka tās ieviešanai ir nepieciešams stingrs normatīvais pamats, jo vienīgi tad būtu iespējama tās efektīva darbība. Ar likumu būtu jānosaka: 1) ka valstij ir pienākums sadarbībā ar sabiedrību veikt ekosistēmu apsaimniekošanu, par pamatu n, nemot ciklisku plānošanu un tās būtiskos komponentus, kas ietver visaptverošu dabas vērtību inventarizāciju un iespējamo apdraudējumu novērtēšanu, ekosistēmas / ainavas / dabas resursa apsaimniekošanas mērķa definēšanu, plāna izstrādi, kurā ir paredzētas rīcības mērķa sasniegšanai; plānoto rīcību îstenošana, rīcību rezultātu monitorings, rīcību novērtēšana un korigéšana, t. i., operatīva rīcības kursa maiṇa, pamatojoties uz informāciju, kas iegūta no iepriekš plānotās rīcības izpildes monitoringa un novērtējuma; 2) pienākums ievērot adaptīvās pārvaldības principus (efektivitāte, elastība - pielāgošanās, sadarbība - līdzdalība); 3) pienākums ievērot noteiktu plānošanas un plānoto rīcību īstenošanas gaitu.

\section{Kopsavilkums}

1. Tiesību dzīvot labvēlīgā vidē ietveršana Satversmē tika saistīta ar mērḳi vides aizsardzību padarìt efektīvāku. Latvijā līdz šim ilgtspējīgas attīstības sociālā pīlāra (cilvēku labklājība) un vides aizsardzības pīlāra konfliktu risināšanā tiesības uz labvēlīgu vidi, kam būtu jāveicina labāka vides aizsardzība, faktiski vides aizsardzības līmeni nav būtiski uzlabojušas. Lai nodrošinātu labāku vides aizsardzību, akūti nepieciešama lielāka konceptuāla skaidrība par to, kā interešu līdzsvarošanas gadījumā būtu izdarāma izvēle starp vides aizsardzības un citām konstitucionāli aizsargātām interesēm (vērtībām).

2. Pašlaik dominējošã antropocentriskā pieeja vides aizsardzībai (vides tiesību antropocentrisms), kas par galveno mērauklu vides aizsardzībai uzskata cilvēku, ir izveidojusies un nostiprinājusies tikai pēdējo piecdesmit gadu laikā. Antropocentrismā balstīta vides aizsardzība ir sociālo, tiesisko un kultūras faktoru noteikta izpratne par cilvēka un dabas mijiedarbības raksturu, taču pati par sevi tā neatspoguḷo minētās mijiedarbības būtību. Speciālajā literatūrā arvien vairāk nostiprinās uzskats, ka antropocentriskā vides aizsardzība pilnīgi neatsedz vides problēmu būtību un līdz galam neapzinās ekologijas sniegtos faktus. Tāpēc ir nobriedusi nepieciešamība vides tiesības padarīt vairāk ekologiskas, tas ir, tādas, kas vairāk atbilstu zinātnes atziņām par cilvēka un dabas mijiedarbības raksturu un būtību.

3. Kā viens no risinājumiem, kas vairāk atbilstu ekolog̣ijas faktiem un ņemtu vērā zinātnes atziṇas, starpdisciplinārajā literatūrā tiek aplūkota valsts un sabiedrības kopīgi īstenota (collaborative governance) adaptīvā pārvaldība (adaptive management). Adaptīvajā pārvaldībā būtiska ir spēja operatīvi pielāgoties mainīgajiem vides apstākḷiem. Šāda vides (ekosistēmu) pārvaldības sistēma ietver strukturētu lēmumu pieṇemšanas un īstenošanas procesu, kur, reagéjot uz jaunu informāciju, noris mācīšanās, kā arī plānoto rīcību pārvērtēšana un pārskatīšana.

3. Izpratne par pārvaldību, kas var risināt ekosistēmu noturības jautājumus, vēl tikai sāk veidoties. Nozīmīgs solis šajā virzienā ir Latvijas vides tiesībās jau iedibinātā

${ }^{42}$ Jenkins V., 2018; Kessen A. M., van Rijswick H. F. M. W., 2012. 
ūdens resursu pārvaldība, kas izmanto ekosistēmas pieeju. Tā ietver vairākus nozīmīgus adaptīvās pārvaldỉbas komponentus. Turpretī sauszemes ekosistēmu pārvaldības sistēmas pašlaik vēl ir l̦oti vājas un neattīstītas.

4. Adaptīvā pārvaldība var būt spēcīgs rīks ekosistēmu noturības veicināšanai. Tās izmantojuma ietvars būtu jāpaplašina un jāattiecina gan uz ūdens, gan sauszemes ekosistēmām. Lai nodrošinātu efektīvu darbību, tās ieviešana būtu jāparedz likumā.

\section{BIBLIOGRĀFIJA}

\section{Literatūra}

1. Birnie P., Boyle A., Redgwell C. International Law \& the Environment. Third edition. New York: Oxford University Press, 2009.

2. Dabas aizsardzība. O. Nikodemus, G. Brūmelis (red.). Rīga: LU Akadēmiskais apgāds, 2015.

3. Grozijumi Latvijas Republikas Satversmē: LV Likums. Latvijas Vēstnesis, 1998. 23. oktobris, Nr. 308/312.

4. Jenkins V. Sustainable Management of Natural Resources: Lessons from Wales. Oxford Journal of Environmental Law, Vol. 30, Issue 3 (November), 2018, pp. 399.-423.

5. Kessen A. M., van Rijswick H. F. M. W. Adaptation to Climate Change in European Water Law. Utrecht Law Review, Vol. 8, Issue 3 (November), 2012, pp. 38-50.

6. Klepfers M. Vides aizsardzība konstitucionālajās tiesībās: Vācijas Pamatlikuma 20.a pants. No: Likums un Tiesības, 5. sēj., Nr. 11 (51), 2003, 322.-328. lpp.

7. Konstitucionālie vides aizsardzības aspekti konstitucionālās tiesas jurisprudencē un citas konstitucionālās jurisprudences problēmas. Viḷna: Lietuvas Republikas Konstitucionālā tiesa, 2009.

8. Lucia V., de. Competing Narratives and Complex Genealogies: The Ecosystem Approach in International Environmental Law. Oxford Journal of Environmental Law, Vol. 27, Issue 1, 2015, pp. 91-117.

9. McDonald J., Styles M. C. Legal Strategies for Adaptive Management under Climate Change. Oxford Journal of Environmental Law, Vol. 26, Issue 1 (March), 2014, pp. 25-53.

10. Meiere S., Čepāne I. Latvijas Republikas Satversmes 115. panta komentārs. No: Latvijas Republikas Satversmes komentāri. VIII nodaļa Cilvēka pamattiesības. Rīga: Latvijas Vēstnesis, 2011.

11. Petersmann M. C. Narcissus' Reflection in the lake: Untold Narratives in Environmental law Beyond the Anthropocentric Frame. Oxford Journal of Environmental Law, Vol. 30, Issue 2, 2018, pp. 235-259.

12. Rubenis A. Ētika 20. gadsimtā. Praktiskā ētika. Rīga: Zvaigzne ABC, 1996.

13. Strautmanis J. Ekologisko tiesību pamati. Dabas vides tiesiskā aizsardzība. Rīga: Zvaigzne ABC, 1997.

14. Turgut N. Y. The Influence of Ecology on Environmental Law: Challenges to the Concept of Traditional Law. RECIEL, 2008.

15. Vides zinātne. M. Kḷaviņš (red.). Rīga: LU Akadēmiskais apgāds, 2008.

16. Young O. R. Navigating the Sustainability Transition: Governing Complex and Dynamic Socioecological Systems. In: Global Environmental Commons. Analytical and Political Challenges in Building Governance Mechanisms. E. Brousseau, T. Dedeurwaerdere, P.-A. Jouvet, M. Willinger (eds.). New York: Oxford University Press, 2012. 


\section{Likumi un normativie akti}

17. Declaration of the United Nations Conference on the Human Environment. Stockholm, 16 June 1972, UN Doc A/CONF/48/14/REV.

18. Latvijas Republikas Satversme: LV Likums. Latvijas Vēstnesis, 1993. 1. jūlijs, Nr. 43.

19. Likums "Par īpaši aizsargājamām dabas teritorijām": LV Likums. Latvijas Vēstnesis, 1993. 25. marts, Nr. 5.

20. Noteikumi par īpaši aizsargājamo dabas teritoriju dabas aizsardzības plāna saturu un izstrādes kārtỉbu: Ministru kabineta 2007. gada 9. oktobra noteikumi Nr. 686. Latvijas Vēstnesis, 2007. 12. oktobris, Nr. 165.

21. Sugu un biotopu aizsardzības likums: LV Likums. Latvijas Vēstnesis, 2000. 5. aprīlis, Nr. 121/122.

22. Ūdens apsaimniekošanas likums: LV Likums. Latvijas Vēstnesis, 2002. 1. oktobris, Nr. 140.

23. Vides aizsardzības likums: LV Likums. Latvijas Vēstnesis, 2006. 15. novembris, Nr. 183.

\section{Juridiskā prakse}

24. Eiropas Cilvēktiesību tiesas spriedums lietā Kyrtatos v. Greece (41666/98).

25. Eiropas Cilvēktiesību tiesas spriedums lietā Hamer v. Belgium (21861/03).

26. Satversmes tiesas 2007. gada 21. decembra spriedums lietā Nr. 2007-12-03. Latvijas Vēstnesis, 2007. 28. decembris, Nr. 207.

27. Satversmes tiesas 2008. gada 17. janvāra spriedums lietā Nr. 2007-11-03. Latvijas Vēstnesis, 2008. 23. janvāris, Nr. 12.

28. Satversmes tiesas 2017. gada 19. decembra spriedums lietā Nr. 2017-02-03. Latvijas Vēstnesis, 2017. 21. decembris, Nr. 254. 